\title{
ANALISIS KEADILAN PROSEDURAL DALAM PENILAIAN KINERJA: PERSPEKTIF SOCIAL EXCHANGE THEORY
}

\author{
Tri Wulida Afrianty 1 \\ Silvia Putriwahyuni ${ }^{2}$ \\ Business Administration Department, Universitas Brawijaya, Jawa Timur, \\ Indonesia ${ }^{1,2}$ \\ Email: twulidafia@ub.ac.id, No telp: (0341) 553737
}

\begin{abstract}
Justice in the organizational context is one of the crucial and interesting issues to be discussed. This is because the issue of justice has a great potential to influence employee attitudes and work behavior. Unfortunately, systematic research and publications on organizational justice, especially procedural justice in organizations in Indonesia are still lacking. Therefore, by using the Social Exchange Theory, this study aims to analyze the effect of procedural justice applied to performance appraisals and the mediating role of satisfaction of performance appraisals on the performance of employees of the Direktorat Jenderal Anggaran, Indonesia. Hierarchical regression analysis was applied to test the hypotheses using SPSS software version 25. The results of this study indicate that: 1) procedural justice applied to performance appraisal has a significant effect on employee performance, 2) procedural justice applied to performance appraisal has a significant effect on the satisfaction of performance appraisal, 3) satisfaction of performance appraisal has a significant influence on employee performance, 4) satisfaction of performance appraisal is proven to have a mediating role on the effect of procedural justice that is applied to performance appraisal on employee performance.
\end{abstract}

Key words: Procedural Justice; Performance Appraisal; Employee Performance; Performance Appraisal Satisfaction; Social Exchange Theory.

\begin{abstract}
ABSTRAK
Keadilan/justice pada konteks organisasi merupakan salah satu isu yang krusial dan menarik untuk dibahas. Hal ini disebabkan isu keadilan memiliki potensi besar untuk mempengaruhi sikap serta perilaku kerja karyawan. Sayangnya, penelitian serta publikasi yang sistematis tentang keadilan organisasional, khususnya keadilan prosedural pada organisasi di Indonesia masih sangat kurang. Oleh karena itu, dengan menggunakan Social Exchange Theory/ Teori Pertukaran Sosial, penelitian ini bertujuan untuk menganalisis pengaruh keadilan prosedural yang diterapkan pada penilaian kinerja serta peran mediasi kepuasan penilaian kinerja terhadap kinerja karyawan Direktorat Jenderal Anggaran, Indonesia. Seluruh hipotesis penelitian ini diuji dengan menggunakan hierarchical regression analysis dengan bantuan SPSS versi 25. Hasil penelitian ini menunjukkan bahwa: 1) keadilan prosedural yang diterapkan pada penilaian kinerja memiliki pengaruh yang signifikan terhadap kinerja karyawan, 2) keadilan prosedural yang diterapkan pada penilaian kinerja memiliki pengaruh yang signifikan terhadap kepuasan penilaian kinerja, 3) kepuasan penilaian kinerja memiliki pengaruh yang signifikan terhadap kinerja karyawan, 4) kepuasan penilaian kinerja terbukti memiliki peran mediasi pada pengaruh keadilan prosedural yang diterapkan pada penilaian kinerja terhadap kinerja karyawan
\end{abstract}

Kata kunci: Keadilan Prosedural; Kinerja Karyawan; Kepuasan Penilaian Kinerja; Teori Pertukaran Sosial. 


\section{PENDAHULUAN}

Keadilan organisasional (organizational justice) merupakan persepsi individu mengenai keadilan yang dirasakan di tempat kerja. Keadilan organisasional merupakan salah satu prediktor yang dapat digunakan untuk menjelaskan sikap dan perilaku kerja karyawan. Dalam literatur manajemen sumber daya manusia, terdapat kesepakatan bahwa keadilan organisasional utamanya meliputi keadilan distributif (distributive justice), keadilan prosedural (procedural justice) dan keadilan interaksional (interactional justice). Herd (2016) menyatakan bahwa teori terkait keadilan prosedural telah secara efektif diterapkan di berbagai aktifitas pengelolaan sumber daya manusia di dalam organisasi, terutama di bidang manajemen kinerja (performance appraisals). Penilaian kinerja merupakan salah satu aktifitas utama dalam pengelolaan sumber daya manusia di dalam organisasi yang bertujuan untuk mengindentifikasi hal-hal yang dapat ditingkatkan dari kinerja karyawan serta dapat dijadikan dasar untuk menetapkan beberapa kebijakan, diantaranya adalah imbalan maupun sanksi (reward and punishment), pelatihan dan pengembangan (training and development) bagi karyawan serta diharapkan dapat mendorong sikap dan perikalu kerja yang positif dari karyawan. Namun, di sisi lain, pelaksanaan penilaian kinerja dapat menjadi suatu sumber ketidakpuasan yang ekstrim jika karyawan merasa bahwa dalam penilaian kinerja terjadi bias, politik atau tidak relevan (Thruston \& McNall, 2010).

Pada konteks manajemen sumber daya manusia, kepuasan dapat diartikan sebagai suatu reaksi emosional individu yang timbul sebagai akibat dari evaluasi 
individu tersebut terhadap dorongan, keinginan, tuntutan, serta harapan-harapannya terkait pekerjaan ataupun hal-hal yang terkait dengan organisasi tempat individu tersebut bekerja yang dihubungkan dengan realita yang dirasakannya. Kaleem (2013) berpendapat bahwa seseorang hanya akan merasa puas dengan proses penilaian kinerja yang telah memenuhi kriteria keadilan. Sebaliknya, penilaian kinerja yang dianggap tidak adil oleh karyawan dapat menyebabkan menurunnya sikap maupun perilaku kerja positif, diantaranya adalah menurunnya kepuasan kerja, berkurangnya bahkan hilangnya komitmen serta kinerja karyawan. Dengan mempertimbangkan besarnya dampak yang dapat ditimbulkan oleh keadilan prosedural ini, maka bahasan serta penelitian tentang keadilan prosedural pada konteks organisasi menjadi menarik dan penting.

Secara keseluruhan, penelitian terdahulu mengenai keadilan prosedural dan dampaknya pada sikap dan perilaku kerja karyawan masih menunjukkan hasil yang belum konklusif (inconclusive). Terkait dengan hal ini, hasil penelitian Wang et al., (2010) menunjukkan bahwa keadilan organisasional (distributif, prosedural, dan interaksional) berpengaruh positif terhadap kinerja karyawan. Sejalan dengan ini, Getnet et al., (2014) dalam penelitiannya menemukan bahwa keadilan prosedural pada penilaian kinerja berpengaruh signifikan terhadap kepuasan penilaian kinerja. Namun, di sisi lain, beberapa penelitian terdahulu menunjukkan hasil yang berbeda. Seperti pada penelitian Warokka et al., (2012) ditemukan bahwa keadilan prosedural pada penilaian kinerja tidak berpengaruh signifikan terhadap kinerja karyawan dan tidak juga memiliki pengaruh yang signifikan terhadap kepuasan penilaian kinerja. Disamping itu, penelitian dan publikasi tentang keadilan 
prosedural pada konteks pengelolaan sumber daya manuasia pada sebuah organisasi lebih banyak dilakukan di negara-negara Barat (Westerns Countries), namun masih terbatas penelitian tentang topik ini yang dilakukan di negara-negara Timur (Eastern Countries), termasuk Indonesia. Dengan mempertimbangkan gap tersebut, maka kami tertarik untuk melakukan penelitian yang menguji pengaruh keadilan prosedural dalam pelaksanaan penilaian kinerja terhadap kinerja karyawan dengan kepuasan penilaian kinerja sebagai variabel intervening

Kami memilih Direktorat Jenderal Anggaran sebagai lokasi penelitian karena institusi ini merupakan salah satu organisasi publik yang memiliki peran sangat penting di Indonesia dengan visi memacu pengelolaan Anggaran Pendapatan dan Belanja Negara (APBN) yang berkualitas untuk mewujudkan pembangunan yang berkelanjutan dan berkeadilan. Sehingga krusial bagi institusi ini untuk menjalankan pengelolaan sumber daya manusianya secara optimal, termasuk menerapkan keadilan prosedural secara efektif pada setiap kegiatannya, tidak terkecuali pada kegiatan penilaian kinerja karyawan. Hal ini sejalan pula dengan pengelolaan kinerja yang diterapkan pada institusi ini yang mengacu pada pada Keputusan Menteri Keuangan Nomor 467/KMK.01/2014. Alasan lainnya adalah penelitian terdahulu terkait keadilan organisasional lebih banyak dilakukan pada organisasi bisnis, masih sangat sedikit penelitian yang dilakukan pada organisasi publik sehingga hasil penelitian ini nantinya dapat memperkaya literatur tentang praktek keadilan organisasional, khususnya keadilan prosedural yang dijalankan pada organisasi. 
Social Exchange Theory (SET) atau teori pertukaran sosial menyatakan bahwa segala bentuk hubungan manusia dilatarbelakangi oleh "asas biaya-manfaat/ subjective-cost and benefit" serta pertimbangan beberapa alternatif (Blau, 1964). Pertukaran sosial melibatkan rasa percaya/ trust dan dibangun berdasarkan prinsip resiprokal (Afrianty, Burgess, \& Issa, 2015). Adapun prinsip resiprokal ini merupakan sebuah prinsip universal yang memiliki 2 (dua) asumsi utama, yaitu: 1) seorang individu seharusnya membantu/menolong individu lain yang telah menolongnya, dan 2) seseorang tidak seharusnya mencelakai atau berbuat buruk terhadap orang yang telah berbuat baik kepadanya (Gouldner, 1960). Atau dengan kata lain, teori pertukaran sosial menekankan pada suatu kondisi yang menyebabkan seorang individu merasa memiliki kewajiban resiprokal positif ketika individu tersebut telah mendapatkan manfaat/hal baik dari pihak lain.

Pada konteks organisasi dan manajemen sumber daya manusia, teori pertukaran sosial telah banyak dipergunakan untuk memahami serta meningkatkan kualitas hubungan antara karyawan dan organisasinya. Secara spesifik, teori ini telah banyak diaplikasikan untuk menjelaskan anteseden yang dapat mendorong sikap maupun perilaku positif karyawan terhadap organisasi tempat karyawan tersebut bekerja (Afrianty, 2013). Karyawan cenderung mengembangkan hubungan yang berkualitas terhadap pihak organisasi berdasarkan pengalaman positif yang mereka peroleh dari organisasinya (Cropanzano \&Mitchell, 2005). Terkait dengan keadilan prosedural yang merupakan fokus pembahasan penelitian ini, Kalay (2016) menyatakan bahwa teori pertukaran sosial dapat menjelaskan dampak dari keadilan prosedural terhadap kinerja karyawan, yang dalam hal ini organisasi 
sebagai arena terjadinya interaksi sosial dan timbal balik jangka panjang antara karyawan dan organisasi. Secara spesifik, dapat dijelaskan bahwa pada konteks penelitian ini, keadilan prosedural merupakan perilaku/ tindakan positif yang dilakukan oleh organisasi terhadap karyawannya. Selanjutnya, karena karyawan telah menerima perlakuan positif dari organisasi berupa keadilan prosedural yang dijalankan dalam penilaian kinerja, maka berdasarkan prinsip resiprokal yang dijadikan dasar dalam teori pertukaran sosial, maka akan timbul perasaan kewajiban dalam diri karyawan untuk membalas perlakuan baik organisasi dengan jalan menunjukkan sikap (yang dalam penelitian ini adalah kepuasan) dan perilaku kerja (yang dalam penelitian ini adalah kinerja) yang positif. Logika inilah yang kami jadikan dasar dalam pengembangan hipotesis penelitian ini (lihat hipotesis penelitian).

Penilaian kinerja merupakan salah satu kegiatan yang sangat penting dalam sebuah organisasi yang dapat dipergunakan sebagai dasar pengambilan kebijakan terkait pemberian balas jasa/kompensasi (reward and punishment) pelatihan dan pengembangan karyawan (training and development) maupun sebagai sarana pemberian umpan-balik (feedback) kepada karyawan berkaitan dengan pekerjaan yang mereka lakukan. Dalam pelaksanaan penilaian kinerja karyawan harus terdapat interaksi yang positif dan berkelanjutan antara atasan dan bawahan.atau antara penilai dan karyawan yang dinilai kinerjanya sehingga dapat menimbulkan kepuasan bagi karyawan yang dinilai. Atau dengan kata lain, sikap dan perilaku positif akan dapat terbentuk jika penilaian kinerja dilakukan dengan mempertimbangkan unsur keadilan. 
Keadilan prosedural merupakan keadilan yang mengacu pada kewajaran prosedur, metode, mekanisme serta proses yang digunakan untuk menentukan dan memutuskan suatu hasil (Palaiologos et al., 2011). Laventhal (1980 dalam Colquit, 2001) menegaskan 6 (enam) hal krusial yang harus diperhatikan dalam keadilan prosedural, yaitu: 1). Konsistensi, yaitu semua karyawan mendapatkan perlakuan yang sama. 2). Menghindari bias, yang dalam hal ini berarti idak ada individu atau kelompok yang didiskriminasi atau diperlakukan buruk. 3). Keakuratan, yaitu keputusan yang dihasilkan harus berdasarkan informasi yang akurat. 4). Representasi semua pihak, yang berari bahwa pihak-pihak terkait dapat memberikan masukan dalam pembuatan keputusan. 5). Koreksi, yaitu memungkinkan adanya perbaikan atau mekanisme lain untuk memperbaiki kesalahan. 6). Etika, yaitu berkaitan dengan norma perilaku profesional yang tidak dilanggar.

Kinerja merupakan implementasi dari teori keseimbangan, yang dalam hal ini berarti bahwa seseorang akan menunjukkan prestasi yang optimal jika orang tersebut mendapatkan manfaat (benefit) dan terdapat rangsangan (inducement) dalam pekerjaannya secara adil dan masuk akal (reasonable) (Wexley \& Yukl dalam Sinambela, 2017). Menurut Wang et al. (2010); Van Scotter \& Motowidlo (1996), kinerja karyawan meliputi: 1). Task Performance, yaitu perilaku spesifik yang mengacu pada suatu pekerjaan seperti tanggung jawab inti pekerjaan yang sesuai dengan job descripton yang secara langsung berhubungan dengan tujuan organisasi. 2). Interpersonal Facilitation, yaitu perilaku yang berorientasi interpersonal yang dapat berkontribusi dalam tercapainya tujuan organisasi, seperti 
semangat kerjasama individu dalam dalam sebuah team work, adanya pertimbangan terhadap orang lain, membangun hubungan baik serta melakukan perbaikan hubungan jika memiliki masalah dengan karyawan lain. 3). Job Dedication, yaitu tindakan-tindakan karyawan yang terkait dengan upaya memotivasi diri dan disiplin diri, seperti mengambil inisiatif serta mengikuti peraturan yang berlaku di perusahaan untuk mendukung tercapainya tujuan.

Kepuasan penilaian kinerja merupakan perasaan karyawan terhadap proses penilaian kinerja, dimana kepuasan ini berfokus terhadap apa yang dirasakan karyawan terkait dengan sistem penilaian kinerja dan umpan balik (Giles \& Mossholder dalam Cowandy, 2014). Menurut Palailogos et al., (2011) dan Jawahar (2007), kepuasan penilaian kinerja mencakup: 1). Satisfaction with Ratings (kepuasan terhadap nilai), dalam hal ini individu yang dinilai cenderung akan puas dengan peringkat/nilai yang mereka yakini sesuai dengan kontribusi yang telah mereka berikan. 2). Satisfaction with Rater (kepuasan terhadap penilai), yaitu kepuasan yang diperoleh dari apa yang telah dilakukan oleh supervisor atau atasan selaku penilai. 3). Satisfaction with Feedback (kepuasan terhadap umpan balik), dalam hal ini umpan balik tidak hanya penting bagi individu tetapi juga bagi organisasi karena pemberian umpan balik memiliki pengaruh yang potensial terhadap kinerja karyawan maupun sikap dan perilaku kerja lainnya.

Berdasarkan Social Exchange Theory/ Teori Pertukaran Sosial yang telah dipaparkan pada bagian awal serta hasil penelitian terdahulu, terdapat 4 (empat) hipotesis dalam penelitian ini, yaitu: 
HI: Keadilan prosedural dalam penilaian kinerja berpengaruh signifikan terhadap kinerja karyawan

$\mathrm{H} 2$ : Kedilan prosedural dalam penilaian kinerja berpengaruh signifikan terhadap kepuasan penilaian kinerja

H3: Kepuasan penilaian kinerja berpengaruh signifikan terhadap kinerja karyawan

H4: Keadilan prosedural berpengaruh signifikan terhadap kinerja karyawan dengan kepuasan penilaian kinerja sebagai variabel intervening

\section{METODE PENELITIAN}

Penelitian ini merupakan jenis penelitian explanatory dengan pendekatan kuantitatif. Penelitian ini berlokasi di Direktorat Jenderal Anggaran, Jakarta. Teknik pengambilan sampel menggunakan proportional random sampling dengan sampel penelitian sebanyak 90 responden Metode pengumpulan data yang dipergunakan dalam penelitian ini adalah questionnaire survey. Pengukuran variabel penelitian ini megadaptasi pengukuran variabel yang telah well established yang telah banyak digunakan di beberapa penelitian sebelumnya dalam berbagai setting penelitian. Dalam penelitian ini, variabel keadadilan prosedural dalam penilaian kinerja menggunakan pengukuran yang dikembangkan oleh Cropanzano et al (2007). Variabel kepuasan penilaian kinerja menggunakan pengukuran yang diadaptasi dari Palaiologos (2011). Adapun variabel kinerja diukur dengan mengadaptasi pengukuran kinerja yang dikembangkan oleh Wang et al (2010). Pengujian hipotesis dilakukan dengan menggunakan hierarchical regression 
analysis. Untuk menguji peran mediasi variabel kepuasan penilaian kinerja pada pengaruh keadilan prosedural dalam penilaian kinerja terhadap kinerja karyawan terdapat empat kondisi yang harus dipenuhi menurut Judd \& Kenny (1981), Baron \& Kenny (1986), Kenny et al., (1998) dalam Shrout and Bolger (2002), yaitu: 1). Variabel $\mathrm{X}$ memiliki hubungan dengan $\mathrm{Y}$ dengan memperkirakan dan menguji koefisien c, dimana Y sebagai outcomes dan X sebagai explanatory variabel. 2). Variabel $\mathrm{X}$ memiliki hubungan dengan $\mathrm{M}$ dengan memperkirakan dan menguji koefisien a, dimana $\mathrm{M}$ sebagai outcomes dan X sebagai explanatory variabel. 3 ). Variabel M memiliki hubungan dengan Y ketika X dimasukkan untuk menguji b, dimana $\mathrm{Y}$ sebagai outcomes dan $\mathrm{X}$ dan $\mathrm{M}$ sebagai explanatory variabel. 4). Langkah terakhir digunakan untuk memperkirakan dan menguji jalur c'. Jika data yang tertera menyatakan bahwa c' tidak sama dengan nol, maka terjadinya mediasi sempurna.

HASIL DAN PEMBAHASAN

Tabel.1

Data Demografi

\begin{tabular}{llllllll}
\hline $\begin{array}{l}\text { Jenis } \\
\text { Kelamin }\end{array}$ & $\%$ & $\begin{array}{l}\text { Usia } \\
\text { (tahun) }\end{array}$ & $\%$ & $\begin{array}{l}\text { Masa } \\
\text { Kerja } \\
\text { (tahun) }\end{array}$ & $\%$ & $\begin{array}{l}\text { Tingkat } \\
\text { Pendidikan }\end{array}$ & $\%$ \\
\hline Laki-laki & 77,8 & $22-26$ & 12,2 & $1-5$ & 24,4 & SMA & 1,1 \\
Perempuan & 22,2 & $27-31$ & 24,4 & $6-10$ & 18,7 & Diploma 3 & 17,8 \\
& & $32-36$ & 12,2 & $11-15$ & 6,5 & Sarjana (S1) & 47,8 \\
& & $37-41$ & 11,1 & $16-20$ & 23,1 & Magister (S2) & 32,2 \\
& $42-46$ & 10 & $21-25$ & 7,6 & Doktoral (S3) & 1,1 \\
& $47-51$ & 15,6 & $26-30$ & 7,6 & & \\
\hline
\end{tabular}

Sumber: data diolah 
Data demografi responden penelitian ini dapat dilihat pada Tabel 1. Dari Tabel 1 terlihat bahwa mayoritas responden penelitian ini adalah laki-laki $(77,8 \%)$, dengan usia mayoritas berada pada rentang $27-31$ tahun $(24,4 \%)$, serta masa kerja terbanyak pada rentang 16-20 tahun dengan latar belakang pendidikan mayoritas adalah sarjana (S1). Sebagaimana yang dijelaskan pada bagian metode penelitian, tekhnik sampling yang dipergunakan adalah proportional random sampling, sehingga keseluruhan responden tersebut mewakili seluruh unit kerja yang ada pada Direktorat Jenderal Anggaran secara proporsional yaitu: 1). Direktorat Penyusunan Anggaran Pendapatan dan Belanja Negara. 2). Direktorat Penerimaan Negara Bukan Pajak. 3). Direktorat Sistem Penganggaran. 4). Sekretariat Direktorat Jenderal. 5). Direktorat Anggaran Bidang Pembangunan Manusia dan Kebudayaan. 6). Direktorat Anggaran Bidang Perekonomian dan Kemaritiman. 7). Direktorat Anggaran Bidang Politik, Hukum, Pertahanan dan Keamanan dan Bagian Anggaran Bendahara Umum Negara. 8). Direktorat Harmonisasi Peraturan Penganggaran. Hasil pengujian hipotesis penelitian ini dapat dilihat pada Tabel 2.

Tabel 2.

Hasil hierarchical regression analysis

\begin{tabular}{llll}
\hline Variabel Independen & $\begin{array}{l}\text { Analisis } \\
\text { Jalur 1 }\end{array}$ & $\begin{array}{l}\text { Analisis } \\
\text { Jalur 2 }\end{array}$ & $\begin{array}{l}\text { Analisis } \\
\text { Jalur 3 }\end{array}$ \\
\cline { 2 - 4 } & Kinerja & Kepuasan & Kinerja \\
Karyawan & $\begin{array}{l}\text { Penilaian } \\
\text { Kinerja }(\mathrm{Z})\end{array}$ & $\begin{array}{l}\text { Karyawan } \\
(\mathrm{Y})\end{array}$ \\
\cline { 2 - 4 } & $\boldsymbol{\beta}$ & $\boldsymbol{\beta}$ & $\boldsymbol{\beta}$ \\
\cline { 2 - 4 } $\begin{array}{l}\text { Keadilan Prosedural dalam Penilaian } \\
\text { Kinerja (X) }\end{array}$ & $\mathbf{0 , 5 4 9 * *}$ & $\mathbf{0 , 6 8 6 * *}$ & $\mathbf{0 , 1 1 7}$ \\
& & & \\
\hline $\mathrm{R}^{2}$ & & & 0,293 \\
\hline
\end{tabular}




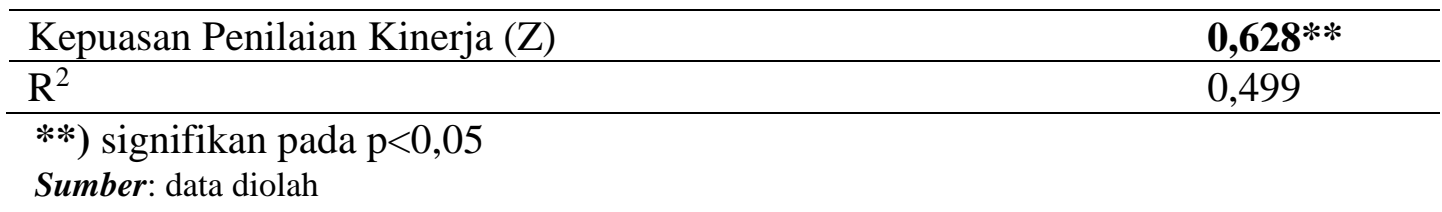

Berdasarkan Tabel 2 dapat diketahui pengaruh masing-masing variabel penelitian yang dapat diuraikan dalam pembahasan berikut. Pengujian hipotesis 1 dapat dilihat pada model 1 pada Tabel 2, dimana dapat diketahui bahwa variabel keadilan prosedural dalam penilaian kinerja berpengaruh signifikan terhadap kinerja karyawan pada nilai signifikansi $\mathrm{p}<0,05$. Selain itu dapat dibuktikan dengan nilai standardized coefficients beta $(\beta)$ sebesar 0,549 , dengan nilai thitung $=6,156$ dan dapat diketahui bahwa nilai $\mathrm{R}^{2}$ sebesar 0,301 . Sehingga dapat disimpulkan bahwa hipotesis 1 diterima. Hasil penelitian ini sesuai dengan penelitian yang dilakukan oleh Wang et al., (2010) yang menyatakan bahwa keadilan organisasi (distributif, prosedural, dan interaksional) berpengaruh terhadap kinerja karyawan.

Hasil penelitian ini sejalan dengan norma timbal balik Social Exchange Theory dimana dukungan positif dari organisasi membuat pegawai memiliki persepsi yang baik dan menganggap dirinya berkewajiban membalas organisasi dengan sesuatu yang baik juga. Salah satunya adalah pegawai akan menampilkan perilaku kerja yang lebih optimal sehingga menghasilkan kinerja yang tinggi.

Pengujian hipotesis 2 dapat melihat model 1 pada Tabel 2, dimana dapat diketahui bahwa variabel keadilan prosedural dalam penilaian kinerja berpengaruh signifikan terhadap kepuasan penilaian kinerja pada nilai signifikansi sebesar $\mathrm{p}<0,05$. Selain itu dapat dibuktikan dengan nilai standardized coefficients beta $(\beta)$ sebesar 0,686, dengan nilai thitung $=8,850$ dan dapat diketahui bahwa nilai $\mathrm{R}^{2}$ sebesar 
0,471. Sehingga dapat disimpulkan bahwa hipotesis 2 diterima. Hasil penelitian ini sesuai dengan penelitian yang dilakukan oleh Getnet et al., (2014) yang menyatakan bahwa keadilan prosedural yang dirasakan karyawan memiliki efek praktis yang signifikan dan kuat pada kepuasan karyawan terhadap praktik penilaian kinerja.

Hasil penemuan ini mendukung pendapat McFarlin \& Sweeny dalam Cowandy (2014) yang menyatakan bahwa sistem penilaian kinerja yang adil akan dapat mempengaruhi kepuasan terhadap penilaian kinerja.

Pengujian hipotesis 3 dapat melihat model 1 pada Tabel 2, dimana dapat diketahui bahwa variabel kepuasan penilaian kinerja berpengaruh signifikan terhadap kinerja karyawan pada nilai signifikansi sebesar $p<0,05$. Selain itu dapat dibuktikan dengan nilai standardized coefficients beta $(\beta)$ sebesar 0,628 , dengan nilai $t_{\text {hitung }}=6,091$ dan dapat diketahui bahwa nilai $\mathrm{R}^{2}$ sebesar 0,499. Sehingga dapat disimpulkan bahwa hipotesis 3 diterima. Hasil penelitian ini sesuai dengan penelitian yang dilakukan oleh Kristyanto dan Fauziyah (2016) yang menemukan bahwa kepuasan penilaian kinerja memiliki pengaruh yang positif dan signifikan terhadap terhadap kinerja karyawan. Hasil penelitian ini juga mendukung pendapat Kuvaas dalam Warokka et al., (2012:7) yang menyatakan bahwa kepuasan terhadap penilaian kinerja dapat menentukan kinerja karyawan itu sendiri. Hal tersebut dapat diartikan bahwa penilaian kinerja digunakan sebagai alat untuk mempengaruhi kinerja karyawan dan jika dikelola dengan benar akan mampu meningkatkan kepuasan karyawan terhadap penilaian kinerja. Karyawan yang merasa puas akan 
mampu meningkatkan kinerjanya. Sehingga, kepuasan penilaian kinerja merupakan prediktor motivasi kedua bagi karyawan untuk meningkatkan kinerjanya (Dorfman et al., Inderrieden et al., Roberts \& Reed dalam Katavich, 2013:17).

Sebagaimana yang telah dijelaskan pada bagian metode penelitian, untuk menguji peran mediasi variabel kepuasan penilaian kinerja pada pengaruh keadilan prosedural dalam penilaian kinerja terhadap kinerja karyawan terdapat empat kondisi yang harus dipenuhi menurut Judd \& Kenny (1981), Baron \& Kenny (1986), Kenny et al., (1998) dalam Shrout and Bolger (2002). Pengujian hipotesis 4 dilakukan berdasarkan keempat kondisi tersebut. Dapat dilihat bahwa pada analisis jalur 1 dalam Tabel 2 terlihat bahwa keadilan prosedural dalam penilaian kinerja memiliki pengaruh signifikan terhadap kinerja karyawan dengan $p<0,05$; koefisien beta sebesar 0,549 ; $t_{\text {hitung }}$ sebesar 6,156 , sehingga syarat pertama terpenuhi. Selanjutnya pada analisis jalur 2 dalam Tabel 1 terlihat bahwa variabel keadilan prosedural dalam penilaian kinerja memiliki pengaruh signifikan terhadap kepuasan penilaian kinerja dengan $\mathrm{p}<0,05$; koefisien beta sebesar 0,686 ; thitung sebesar 8,850, sehingga syarat kedua terpenuhi. Pada analisis jalur 3 dalam Tabel 1 terlihat bahwa variabel kepuasan penilaian kinerja memiliki pengaruh signifikan terhadap kinerja karyawan dengan $\mathrm{p}<0,05$; koefisien beta sebesar 0,628 ; $\mathrm{t}_{\text {hitung }}$ sebesar 6,091, sehingga syarat ketiga terpenuhi. Setelah ketiga syarat uji mediasi terpenuhi, maka kemudian peneliti membandingkan pengaruh keadilan prosedural dalam penilaian kinerja terhadap kinerja karyawan terlihat bahwa pengaruh keadilan prosedural dalam penilaian kinerja terhadap kinerja karyawan setelah variabel mediasi dimasukkan (pada model 3) menjadi tidak signifikan dengan 
koefisien beta sebesar sebesar 0,117 ; $t_{\text {hitung }}$ sebesar 1,138;p>0,05. Berdasarkan perbandingan tersebut maka peneliti menyimpulkan bahwa kepuasan penilaian kinerja memediasi secara sempurna (fully mediated). Sehingga dapat disimpulkan bahwa hipotesis 4 diterima. Hasil penelitian ini mendukung pendapat McFarlin \& Sweeny dalam Cowandy $(2014 ; 22)$ yang menyatakan bahwa sistem penilaian kinerja yang adil akan dapat mempengaruhi kepuasan terhadap penilaian kinerja dan dapat memberikan landasan motivasi bagi karyawan untuk meningkatkan kinerja dimasa yang akan datang

\section{SIMPULAN DAN SARAN}

Secara keseluruhan, hasil penelitian ini mengkonfirmasi Social Exchange Theory/ Teori Pertukaran Sosial sebagai penjelas sikap dan perilaku karyawan di tempat kerja. Dalam hal ini, pelaksanaan penilaian kinerja yang dipersepsikan adil oleh karyawan mampu untuk meningkatkan kepuasan terhadap penilaian kinerja tersebut maupun kinerja karyawan. Secara detail, hasil penelitian ini menunjukkan bahwa: 1). Keadilan prosedural dalam penilaian kinerja memiliki pengaruh signifikan terhadap kinerja karyawan. 2). Keadilan prosedural dalam penilaian kinerja memiliki pengaruh signifikan terhadap kepuasan penilaian kinerja. 3). Kepuasan penilaian kinerja memiliki pengaruh signifikan terhadap kinerja karyawan. 4). Penilaian kinerja memediasi pengaruh keadilan prosedural dalam penilaian kinerja terhadap kinerja karyawan. 
Penelitian ini mengukur kinerja karyawan dengan menggunakan metode self-report yang memungkinkan timbulnya social desirability bias. Oleh karena itu, untuk penelitian selanjutnya dalam mengukur kinerja karyawan, peneliti dapat mempertimbangkan untuk menggunakan kuesioner berpasangan (paired questionnaire) dengan memberikan kuesioner kepada atasan ataupun rekan kerja untuk mengukur kinerja karyawan untuk memperoleh hasil yang lebih obyektif

\section{REFERENSI}

Afrianty, T. W. (2013). Work Life Balance Policies in the Indonesian Context. (November), $267 . \quad$ Retrieved from http://espace.library.curtin.edu.au/R?func=dbin-jumpfull\&local_base=gen01era02\&object_id=199554

Afrianty, T. W., Burgess, J., \& Issa, T. (2015). Family-friendly support programs and work family conflict among Indonesian higher education employees. Equality, Diversity and Inclusion, 34(8), 726-741. https://doi.org/10.1108/EDI-04-2015-0026

Anastasios Palaiologos, P. P. (2011). Organizational Justice and Employee Satisfaction In Performance Appraisal. Journal of European Industrial Training, $X X X V(8), 826-840$.

Baron, R. M., \& Kenny, D. A. (1986). The moderator-mediator variable distinction in social psychological research: conceptual, strategic, and statistical consideration. Journal of personality and social psychology, 51(61) pp. 1173-1182

Blau, P. (1964). Exchange and power in social life. New York: Wiley Colquitt, J. A. 2001. On the dimensionality of organizational justice: A construct validation of a measure. Journal of Applied Psychology, 86: 356-400

Cowandy, C. J. (2014). The Impact of Fair Performance Appraisal to Employee Motivation and Satisfaction Towards Performance Appraisal - A Case of PT. XYZ. iBuss Management, II, 21-28. 
Cropanzano, R., \& Mitchell, M. S. (2005). Social Exchange Theory: An Interdisciplinary Review. Journal of Management, 31(6), pp. 874-900.

Cropanzano, R., Bowen, D. E., \& Gilliland, S. W. (2007). The Management of Organisational Justice. Academy of Management Prespectives, 31- 48.

Getnet, B., Jabena, T., \& Tsegaye, A. (2014). The Effect Of Employee's Fairness Perception On Their Satisfaction Towards The Performance Appraisal Practices (A Case Study Of University Of Gondar). International Journal Management and Commerce Innovation, 2(1), pp. 174-210.

Herd, D. A. (2016, August 11). An Examination of LMX And Procedural Justice on Performance Appraisal Satisfaction within the Context of a Distributed Workplace Arrangement. Human Resource Development Theses and Dissertation, paper 15. University of Texas at Tyler

Kaleem, M. M., Jabeen, B., \& Twana, M. J. (2013). Organizational Justice in Performance Appraisal System: Impact on Employees Satisfaction and Work Performance. International Journal of Management \& Organizational Studies, 2(2), 28-37

Katavich, K. M. (2013). https://mro.massey.ac.nz/. Diambil kembali dari Massey University, University Of New Zealand: http://hdl.handle.net/10179/5708

Kristyanto, A., \& Fauziyah, F. A. (2016). Pengaruh Keadilan Distributif Pada Penilaian Kinerja Terhadap Kinerja Karyawan yang Dimediasi Oleh Kepuasan Penilaian Kinerja di PT.DOK dan Perkapalan Surabaya. Jurnal Ekonomi, Bisnis, dan Kewirausahaan, 5(1), pp. 1-23.

Palailogos, A., Papazekos, P., \& Pnayotopoulou, L. (2011). Organizational Justice and Employee Satisfaction in Performance Appraisal. Journal of Europan Industrial Training, 35(8), 826-840.

Shrout, P. E., \& Bolger, N. (2002). Mediation in Experimental and Nonexperimental Studies: New Procedures and Reecommendations. Psychological Methods, 7(4) pp. 422-445.

Sinambela, L. P. (2017). Manajemen Sumber Daya Manusia. Jakarta: Bumi Aksara.

Thruston Jr, P. W., \& McNall, L. (2010). Justice Perceptions of Performance Appraisal Practices. Journal Managerial Psychology, 25(3) pp.201-228.

Wang, X., Lia, J., Xia, D., \& Chang, T. (2010). The Impact Of Organizational Justice on Work Performance: Mediating Effects Of Organizational Commitment and Leader Member Exchange. International Journal of Manpower, 31(6), 660-677. 
Tri Wulida Afrianty dan Silvia Putriwahyuni. Analisis Keadilan Prosedural Dalam......

Warokka, A., Gallato, C. G., \& Moorthy, T. a. (2012). Organizational Justice in Performance Appraisal System and Work Performance: Evidence From an Emerging Market. Journal of Human Resources Management Research, 118. 